\title{
IMPROVING AGENTS FOR PHYTOREMEDIATION OF SOIL CONTAMINATED WITH PYMETROZINE INSECTICIDE
}

\author{
Aly A.A. Shalaby ${ }^{\text {* }}$, A.A.A. Aioub ${ }^{1}$, A.A.A. Romeh $^{2}$ and M.R.A. Ramadan ${ }^{2}$ \\ 1. Plant Prot. Dept., Fac. Agric., Zagazig Univ., Egypt \\ 2. Plant Prod. Dept., Fac. Technol. and Dev., Zagazig Univ., Egypt
}

Received: 22/02/2017 ; Accepted: 13/03/2017

\begin{abstract}
The present work was designed to investigate the potential of using plantain (Plantago major L.) for the phytoremediation of pymetrozine contaminated soil. The use of soluble silicon dioxide $\left(\mathrm{SiO}_{2}\right)$, Tween 80 , hydroxypropyl- $\beta$-cyclodextrin $(\mathrm{HP} \beta \mathrm{CD})$ and liquid humic acid (HA) for enhancing the availability and uptake of pymetrozine contaminated soil by $P$. major were evaluated. Results revealed that pymetrozine concentrations in soil with $P$. major reduced by $30.00-$ $83.25 \%$ throughout 1 to 12 days exposure, compared with $12.50-61.90 \%$ in the soil of control. Pymetrozine uptake in the roots and translocated in the leaves of $P$. major to reach the maximum levels, $53.41 \mathrm{mg} / \mathrm{kg}$ and $58.08 \mathrm{mg} / \mathrm{kg}$, respectively, after 4 days. The phytoremediation efficiency of $P$. major amended with $\mathrm{SiO}_{2}$ was greater than that of other solubility-enhancing agents with respect to the removal of pymetrozine from contaminated soil within 1-12 days of treatment. The addition of $\mathrm{SiO}_{2}$ increased pymetrozine uptake in roots and translocation in leaves by about $170.84 \%$ and $322.83 \%$ compared with $P$. major roots and leaves alone, respectively within 4 days. The most-effective to least-effective supplements to use in combination with $P$. major for the purpose of pymetrozine phytoremediation in roots and leaves were found to be as follows: $\mathrm{SiO}_{2}>\mathrm{HA}>\mathrm{HP} \beta \mathrm{CD}>$ Tween 80 . This study indicates that $\mathrm{SiO}_{2}$ can improve the efficiency of phytoremediation of pymetrozine.
\end{abstract}

Key words: Phytoremediation, Plantago major, pymetrozine, improving agents, soil.

\section{INTRODUCTION}

Pymetrozine was the compound of the pyridine azomethine family, representing a newly developed chemical class of insecticides (Shen et al., 2009). Pymetrozine is efficient toward aphids, whiteflies and plant hoppers in pest control programmes (Lashkari et al., 2007). Pymetrozine acts by interfering in the regulation of the nervous system for feeding behavior, which results in death of the insect due to starvation a few days after application (Guoqing et al., 2009). EFSA (2014) showed that pymetrozine exhibits low to moderate persistence in soil under laboratory aerobic conditions. It degraded by hydroxylation of the methylene group of the triazine ring and by oxidation. Degradation under field conditions

\footnotetext{
${ }^{*}$ Corresponding author: Tel. : +2001278194994

E-mail address: aaashalaby@zu.edu.eg
}

from 8 sites in Europe (Switzerland, France and Germany) resulted in pymetrozine dissipating with single first order $\mathrm{DT}_{50}$ of $19.6-183 \mathrm{~d}$ (5sites) and biphasic $\mathrm{DT}_{50}$ 3.81-10.3 d with associated $\mathrm{DT}_{90} 167 \geq 1000$ d. Pymetrozine degraded from water mainly by distribution to the sediment. Single first order $\mathrm{DT}_{50}$ of pymetrozine in the whole systems ranged between 289 and $495 \mathrm{~d}$.

Phytoremediation is an environmentally sound technology for pollution prevention, control and remediation. One medicinal herb is plantain (Plantago major L., Plantaginacea family). Plantago major has a wide geographic distribution through the temperate grasslands of the world and grows in a wide area of Europe, temperate regions of Asia and South Australia, North Africa and North America (Velasco- 
Lezama et al., 2006). It is a familiar perennial weed and may be found at roadsides, meadowlands, cultivated fields, waste areas, and even cracks in sidewalks and canal banks. The seeds and husks contain high levels of fiber; they expand and become highly gelatinous when soaked in water (Samuelsen, 2000; Sharifa et al., 2008). P. major can accumulate a variety of inorganic metals or metabolize a variety of organic compounds including imidacloprid, chlorpyrifos, diethyl and dioctyl phthalates, azoxystrobin and cyanophos (Romeh, 2010; Romeh, 2013; Romeh and Hendawi, 2013 ; Romeh, 2014; Romeh, 2015a\&b). Therefore, the goal of this work was to assess the capability of using $P$. major for the phytoremediation of pymetrozine -contaminated soil. The utilization of soluble silicon dioxide $\left(\mathrm{SiO}_{2}\right)$ and improving agents such as the surfactants, Tween 80, hydroxypropyl- $\beta$-cyclodextrin (HP $\beta C D$ ) and liquid humic acid (HA) for enhancing the bioavailability and uptake of pymetrozine contaminated soil by $P$. major were evaluated.

\section{MATERIALS AND METHODS}

\section{Pesticide and Plant}

Pymetrozine (Technical grade 95.00\%), 6methyl-4-[(E)- pyridin-3-ylmethylideneamino]2, 5-dihydro-1, 2, 4-triazin-3-one was acquired from Central Agricultural Pesticides Laboratory, Agricultural Research Center, Dokki - Giza, Egypt. The normal broadleaf plantain (P. major) was acquired as seedlings in phytoremediation experiment. Seeds of $P$. major grow naturally on meadow land in Zagazig University, Zagazig, Sharkia Governorate. After the seeds germinated, the seedlings (the age of the seedlings is 30 days and $10-12 \mathrm{~cm}$ height with 4 -6 leaves) were collected for the experiment.

\section{Experimental Design}

To assess the elimination of pymetrozine from the soil, two treatments were performed in this experiment, and each treatment consisted of five replicates: pymetrozine contaminated soil without plants, pymetrozine contaminated soil with $P$. major only (each pot contained one seedling of $P$. major). Experimental uptake was performed on soil in a pot experiment for 21-day exposure. Air-dried sieved clay loam soil (organic matter, $1.79 \%, \mathrm{pH} 7.8$, electric conductivity 2.36) was obtained from Kamrona Village, Menia EL-Kamh district, Sharkia Governorate, Egypt, and then placed in plastic pots. The pots were provided with $0.5 \mathrm{~kg}$ of air dried soil. After planting, pymetrozine dissolved in water was spiked into the $150 \mathrm{ml}$ of distilled water used for irrigation to obtain the original concentration of $20 \mathrm{mg} / \mathrm{kg}$. The irrigation water containing pymetrozine was dropped into the pots with a caution to avoid the direct contact of plant leaves. Samples from exposed and control plants were collected through 1, 3, 7, 10, 14 and 21 days. Roots of plant from soil were rinsed in running tap water for $2 \mathrm{~min}$ and were blotted dry. The plants were dissected into individual roots and leaves then, $10 \mathrm{~g}$ of each leaves and roots and $20 \mathrm{~g}$ of soil were analyzed for the pesticide. All pots were watered with $50 \mathrm{ml}$ tap water every 4 days or additionally watered when essential.

\section{Enhancing Agents for Phytoremediation of Soil Contaminated by Pymetrozine}

To assess the removal of pymetrozine from the soil, eight treatments each consisting of five replicates were performed, as follows: Autoclaved soil contaminated with pymetrozine without plants. Soil contaminated by pymetrozine without plants. Contaminated soil with pymetrozine plus $P$. major only. Contaminated autoclaved soil with Pymetrozine containing $P$. major only. Contaminated soil with pymetrozine plus $P$. major and amended with soluble silicon dioxide $\left(\mathrm{SiO}_{2}\right)$, these called silica, at $750 \mathrm{mg} / \mathrm{l}$ for a total concentration of $187.5 \mathrm{mg} / \mathrm{kg}$. Contaminated soil with pymetrozine plus $P$. major and amended with 2Hydroxypropyl-beta-cyclodextrin (HP $\beta C D)$ at $1.0 \%$ (Chen et al., 2010). Contaminated soil with pymetrozine plus $P$. major and amended with humic acid solution (HA) at $10 \mathrm{mg} / \mathrm{l}$ (humus WSG 90, produced by organistHungary). The latter concentration is reported to be the critical micelle concentration of HA (Guetzloff and Rice, 1994). Contaminated soil with pymetrozine plus $P$. major and amended with polyoxyethylene sorbitan monooleate (Tween 80 ) at $9.2 \mathrm{mg} / \mathrm{l}$, corresponding to 0.5 critical micelle concentration (CMC), where the CMC of Tween 80 was determined as 13-45 mg/l (Edwards et al., 1991; Mitton et al., 2012). 
In treatments (3)-(8), each pot contained one seedling of $P$. major. Each whole plant uptake experiment was performed in potted soil for 12 days as described above.

\section{Residues Analysis}

The system followed in this work depended on QuEChERS strategy depicted by Anastassiades et al. (2003) and Lehotay et al. (2005). Soil tests were homogenized sieved (2 $\mathrm{mm}$ mesh) and air-dried at room temperature. A $10 \mathrm{~g}$ of homogenised soil was weighed into a 50 $\mathrm{ml}$ polypropylene tube, then $5 \mathrm{ml}$ of HPLC water was included and the mixture was shaken for 1 min with a vortex apparatus. After that 10 $\mathrm{ml}$ of acetonitrile was included (acidified with acetic acid 1\%) and the mixture was shaken for $1 \mathrm{~min}$ by hand and for $1 \mathrm{~min}$ with a vortex apparatus. Four grams of anhydrous magnesium sulfate, and $1 \mathrm{~g}$ sodium chloride were added, and the mixture was instantly hand-shaken for $30 \mathrm{sec}$., and centrifuged for $5 \mathrm{~min}$ at $4000 \mathrm{rpm}$ in a Sigma 2-5 rotator (Sigma, Steinheim, Germany). At that point, a clean-up dispersive solid phase extraction step was implemented by including the supernatant $(7.5 \mathrm{ml}$, i.e. $1.33 \mathrm{~g}$ of soil for every $\mathrm{ml}$ ), to a $15 \mathrm{ml}$ polypropylene tube that contained $1.125 \mathrm{~g}$ of $\mathrm{MgSO}_{4}(150 \mathrm{mg}$ $\mathrm{MgSO}_{4}$ per $\mathrm{ml}$ of concentrate) and $0.225 \mathrm{~g}$ of $\mathrm{C}_{18}$ (30 mg $\mathrm{C}_{18}$ per $\mathrm{ml}$ of concentrate), handshaken for $30 \mathrm{sec}$. and centrifuged for $5 \mathrm{~min}$ at 4000 rpm (Asensio-Ramos et al., 2010; PadillaSanchez et al., 2010). For the determination of pymetrozine, $1.0 \mathrm{ml}$ of the final concentrate was determined by HPLC.

A $10 \mathrm{~g}$ of fine macerated plant tissue (roots or leaves) was weighed into a $50 \mathrm{ml}$ polypropylene tube. Then, $10 \mathrm{ml}$ of acetonitrile was added (acidified with acetic acid 1\%) and the mixture was hand-shaken for $2 \mathrm{~min}$. Four grams anhydrous magnesium sulfate, and $1 \mathrm{~g}$ sodium chloride, was added, and the mixture was immediately hand-shaken for $30 \mathrm{sec}$. and centrifuged for $5 \mathrm{~min}$ at $4000 \mathrm{rpm}$. The clean-up step was implemented by adding the supernatant ( $7.5 \mathrm{ml}$, i.e. $1.33 \mathrm{~g}$ of plant tissue per $\mathrm{ml}$ ), to a $15 \mathrm{ml}$ polypropylene tube that included $1.125 \mathrm{~g}$ of $\mathrm{MgSO}_{4}(150 \mathrm{mg} \mathrm{MgSO}$ per $\mathrm{ml}$ of extract), and $0.188 \mathrm{~g}$ of PSA $(25 \mathrm{mg}$ PSA per $\mathrm{ml}$ of extract), hand-shaken for $30 \mathrm{sec}$. and centrifuged for $5 \mathrm{~min}$ at $4000 \mathrm{rpm}$ (Anastassiades et al.,
2003; Lehotay et al., 2005). For the determination of pymetrozine residues, $1.0 \mathrm{ml}$ of the final extract was analyzed by HPLC.

\section{HPLC analysis}

Soil, root, and leaf samples were analyzed for pymetrozine using high-performance liquid chromatography (HPLC) according to (Shen et al., 2009). A $10 \mu l$ aliquot of final extract was injected into HPLC system and determined using a $\mathrm{C}_{18}$ reversed-phase column [250 $\mathrm{mm} \mathrm{x}$ $4.6 \mathrm{~mm}$ (i.d.)] and eluted isocratically with a mobile phase of water and acetonitrile (15:85, $V / V)$ at the rate of $1 \mathrm{ml} / \mathrm{min}$. The UV detection was adjusted at $299 \mathrm{~nm}$. The retention time (RT's) was 2.63 minutes under these conditions. The performance of HPLC method was tested by evaluating quality parameters, such as recovery values.

\section{Recovery Samples}

The extraction effectiveness of the analytical procedure was assessed by recovery experiments prepared in triplicate using the fortified blank leaves and roots of $P$. major, and soil samples at $0.5 \mathrm{mg} / \mathrm{kg}$. The percent recoveries were respectively, $92.33,90.12$, and $88.5 \%$ in roots, leaves, and soils.

\section{Data Analysis}

The rate of degradation $\left(\mathrm{K}_{\mathrm{r}}\right)$ and half-life $\left(t_{1 / 2}\right)$ was obtained according to Gomaa and Belal (1975) and Ashour (1976). The rate of degradation $\left(\mathrm{K}_{\mathrm{r}}\right)=2.303 \times$ xlope. Half-life $\left(\mathrm{t}_{1 / 2}\right)$ $=0.693 / \mathrm{K}_{\mathrm{r}}$.

\section{RESULTS AND DISCUSSION}

\section{Phytoremediation of Soil Contaminated with Pymetrozine}

Results obtained during the present investigation revealed that all experimental sets containing plantain removed a high amount of pymetrozine. As shown in Table 1, pymetrozine concentrations in soil containing $P$. major declined by $30.00-83.25 \%$ during 1 to 12 days of the experimental period, compared with $12.50-61.90 \%$ in un-planted soil. The half-life value $\left(t_{1 / 2}\right)$ of pymetrozine, estimated by firstorder reaction, for soil plus $P$. major was found to be 5.65 days, compared with 8.58 days for 
Table 1. Dissipation of pymetrozine in soil planted with Plantago major $\mathbf{L}$

\begin{tabular}{|c|c|c|c|c|c|c|c|c|c|}
\hline \multirow[t]{2}{*}{ Treatment } & \multicolumn{9}{|c|}{ Days after application } \\
\hline & 1 & 2 & 4 & 6 & 8 & 12 & $\begin{array}{c}\mathrm{T}_{1 / 2} \\
\text { (days) }\end{array}$ & $\begin{array}{c}\mathrm{K}_{\mathrm{r}} \\
\text { (days) }\end{array}$ & $\begin{array}{c}\mathrm{AUC} \mathrm{C}_{\mathrm{s}} \mathrm{mg} / \mathrm{kg} \\
\text { (days) }\end{array}$ \\
\hline \multicolumn{10}{|l|}{ In soil } \\
\hline $\mathrm{mg} / \mathrm{kg}$ & 17.50 & 15.30 & 13.52 & 11.40 & 9.05 & 7.62 & 8.58 & 0.08 & 142.19 \\
\hline $\operatorname{Loss}(\%)$ & 12.50 & 23.50 & 32.40 & 43.00 & 54.75 & 61.90 & & & \\
\hline \multicolumn{10}{|c|}{ In soil with $P$. major } \\
\hline $\mathrm{mg} / \mathrm{kg}$ & 14.00 & 11.52 & 9.71 & 7.87 & 5.66 & 3.35 & 5.65 & 0.12 & 97.45 \\
\hline Loss (\%) & 30.00 & 42.40 & 51.45 & 60.65 & 71.70 & 83.25 & & & \\
\hline \multicolumn{10}{|c|}{ In $P$. major roots } \\
\hline $\mathrm{mg} / \mathrm{kg}$ & 38.74 & 45.56 & 53.41 & 42.91 & 37.69 & 22.58 & & & \\
\hline \multicolumn{10}{|c|}{ In $P$. major leaves } \\
\hline $\mathrm{mg} / \mathrm{kg}$ & 13.58 & 44.95 & 58.08 & 37.72 & 28.13 & 16.06 & & & \\
\hline Total uptake & 52.32 & 90.51 & 111.49 & 80.63 & 65.82 & 38.64 & & & \\
\hline
\end{tabular}

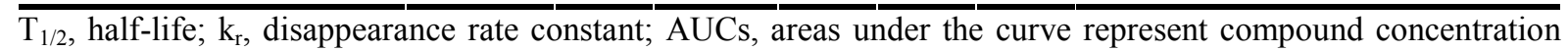
during the period of study

soil alone (Table 1). Results with the disappearance rate constant $(\mathrm{kr})$ values showed that pymetrozine had the highest $k_{r}$ value and lowest $t_{1 / 2}$ in soil with $P$. major, while pymetrozine had the shortest $\mathrm{k}_{\mathrm{r}}$ and longest $\mathrm{t}_{1 / 2}$ in unplanted soil.

Pymetrozine concentrations $(\mathrm{mg} / \mathrm{kg})$ in various parts of $P$. major are found in Fig. 1. Concentrations of pymetrozine in the root were always higher than those in the leaves of the plant, with the exception of 4 days period; the translocation ratio was about 1.08 times higher than for pymetrozine contaminated soil with $P$. major roots (Fig. 1). In the roots of P. major, pymetrozine accumulated to reach the maximum levels through 4 days $(53.41 \mathrm{mg} / \mathrm{kg})$. Afterwards, concentration decreased gradually during the experiment (Table 1). Pymetrozine translocated into the leaves of $P$. major and reached the maximum through 4 days of treatment $(58.08 \mathrm{mg} / \mathrm{kg})$ then decreased until the end of exposure. Pymetrozine is highly moved in plants. It can be taken up from the soil as well as through the leaves (Fliickige et al., 1992). Pymetrozine is both systemic and translaminar, making it highly mobile within plants (Wyss and Bolsinger, 1997). From bioassays and autoradiographic techniques of pymetrozine, it has been shown that this systemic behavior originates not only from xylem but also from phloem mobility. After foliar application, the growing points of plants are protected by pymetrozine imports mainly from leaves. This indicates a high importance of phloem mobility for the systemic activity of pymetrozine for plant-sucking insects (Wyss and Bolsinger, 1997).

\section{Combination of $P$. major and Agents that Increase the Pymetrozine Availability in Soil}

Changes in the levels of pymetrozine in soils subject to various treatments were measured following 1 to 12 days (Table 2) to estimate (1) plant's capacity to remove pymetrozine, (2) the role of various agents in increasing pymetrozine accessibility, microorganisms, plants and combination of plants with microorganisms, which lead to the dissipation of pymetrozine in the soil. Different agents contributed in increasing pymetrozine availability and reached the maximum enhancing through $4-8$ days; therefore, the removal percentage of pymetrozine in a control group (C) was compared with removal percentages in experimental treatments after 4 days. 


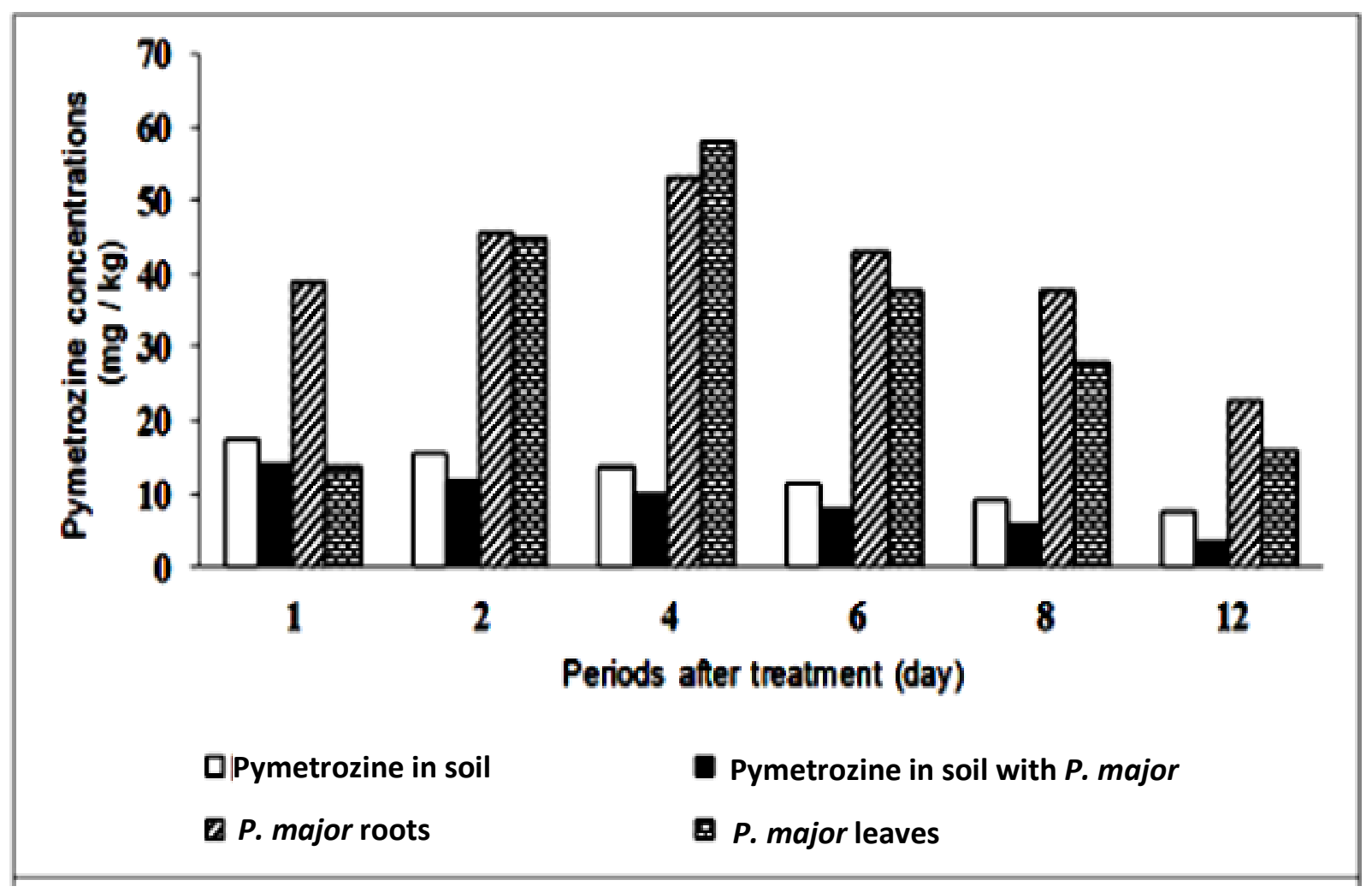

Fig. 1. Uptake and translocation of pymetrozine by Plantago major L. in soil

In $\mathrm{C}, 24.70 \%$ of the pymetrozine was degraded through natural biotic losses, whereas degradation percentages in treatments $\mathrm{T}_{1}, \mathrm{~T}_{2}$, and $\mathrm{T}_{3}$ were $32.40 \%, 49.50 \%$, and $51.45 \%$, respectively. We examined the contribution of three factors in the degradation of pymetrozine: biotic dissipation or natural hydrolyzation, as in the control group $(\mathrm{C})$, microbial dissipation $\left(\mathrm{T}_{1}\right)$, remediation by $P$. major $\left(\mathrm{T}_{2}\right)$, and a combination of microbial degradation and $P$. major remediation $\left(\mathrm{T}_{3}\right)$ (Table 2). Abiotic degradation was not considered in the treatments. The degradation of pymetrozine in the soil due to contribution by microorganisms $\left(T_{1}\right)$ was $7.70 \%$, while contribution by plant alone $\left(\mathrm{T}_{2}\right)$ and a combination of microorganisms and plants $\left(\mathrm{T}_{3}\right)$ resulted in dissipation amounts of $24.80 \%$ and $26.75 \%$, respectively. The results showed that a combination of microorganisms plus plants $\left(\mathrm{T}_{3}\right)$ is the most effective treatment for the dissipation of pymetrozine in soil, followed by plant alone $\left(T_{2}\right)$ and then microorganisms $\left(T_{1}\right)$, compared with natural dissipation processes.
It could be concluded that enhancement in pymetrozine dissipation in phytoremediation system could be achieved possibly due to the degradation induced by effects of plant with microorganisms in rhizosphere (Cheng et al., 2007). The microbial-enhanced phytoremediation offers much potential for the remediation of organic pollutants in the soil (Chen et al., 2010).

Pollutant-degrading bacteria may accelerate plants adaptation to contaminants by detoxifying contaminated soils during direct mineralization of these organic contaminants (EscalanteEspinosa et al., 2005). In addition to, plant exudates increase the density and activity of potential pollutant-degrading bacteria in the area surrounding the roots (Siciliano and Germida, 1998). Romeh (2010) found that short-rod gramnegative bacteria that isolated from the water solution containing $P$. major was able to induce 93.34\% loss of imidacloprid as a source of both nitrogen and carbon through $48 \mathrm{hr}$. 
Table 2. Contribution of agents that increase the pymetrozine availability in soil

\begin{tabular}{|c|c|c|c|}
\hline Treatment & & Day & $s$ after treatments \\
\hline Amount added to the soil $(20 \mathrm{mg} / \mathrm{kg})$ & $\mathrm{mg} / \mathrm{kg}$ & Removal (\%) & Contribution (\%) \\
\hline 1 day & & & \\
\hline C:In autoclaved soil & 18.55 & 7.25 & 0.0 \\
\hline T1: In soil & 17.50 & 12.50 & 5.25 microorganisms $\left(\mathrm{T}_{1}-\mathrm{C}\right)$ \\
\hline T2: Autoclaved soil with plantain & 14.30 & 28.50 & 21.25 Plant $\left(\mathrm{T}_{2}-\mathrm{C}\right)$ \\
\hline T3: Soil with plantain & 14.00 & 30.00 & 22.75 Combination $\left(\mathrm{T}_{3}-\mathrm{C}\right)$ \\
\hline T4: Soil with plantain $+\mathrm{SiO} 2$ & 11.10 & 44.50 & $14.50 \mathrm{SiO}_{2}\left(\mathrm{~T}_{4^{-}} \mathrm{T}_{3}\right)$ \\
\hline T5: Soil with plantain + HPßCD & 11.20 & 44.00 & $14.00 \mathrm{HP} \beta \mathrm{CD}\left(\mathrm{T}_{5}-\mathrm{T}_{3}\right)$ \\
\hline T6: Soil with plantain + HA & 11.16 & 44.20 & 14.20 Humic acid $\left(\mathrm{T}_{6}-\mathrm{T}_{3}\right)$ \\
\hline T7: Soil with plantain +Tw 80 & 11.60 & 42.00 & $12.00 \mathrm{Tw} 80\left(\mathrm{~T}_{7}-\mathrm{T}_{3}\right)$ \\
\hline 2 days & & & \\
\hline C:In autoclaved soil & 17.39 & 13.05 & 0.0 \\
\hline T1: In soil & 15.30 & 23.50 & 10.45 microorganisms (T1-C) \\
\hline T2: Autoclaved soil with plantain & 12.00 & 40.00 & 26.95 Plant (T2-C) \\
\hline T3: Soil with plantain & 11.52 & 42.40 & 29.35 Combination (T3-C) \\
\hline T4: Soil with plantain $+\mathrm{SiO} 2$ & 7.42 & 62.90 & $20.50 \mathrm{SiO} 2(\mathrm{~T} 4-\mathrm{T} 3)$ \\
\hline T5: Soil with plantain + HPßCD & 8.24 & 58.80 & 16.40 HP $\beta C D$ (T5- T3) \\
\hline T6: Soil with plantain + HA & 7.71 & 61.45 & 19.05 Humic acid (T6- T3) \\
\hline T7: Soil with plantain+ Tw 80 & 8.80 & 56.00 & 13.60 Tw 80 (T7- T3) \\
\hline 4 days & & & \\
\hline C:In autoclaved soil & 15.06 & 24.70 & 0.0 \\
\hline T1: In soil & 13.52 & 32.40 & 7.70 microorganisms $(\mathrm{T} 1-\mathrm{C})$ \\
\hline T2: Autoclaved soil with plantain & 10.10 & 49.50 & 24.80 Plant (T2-C) \\
\hline T3: Soil with plantain & 9.71 & 51.45 & 26.75 Combination (T3-C) \\
\hline T4: Soil with plantain $+\mathrm{SiO} 2$ & 5.30 & 73.50 & $22.05 \mathrm{SiO} 2(\mathrm{~T} 4-\mathrm{T} 3)$ \\
\hline T5: Soil with plantain + HPßCD & 6.45 & 67.75 & $16.30 \mathrm{HP} \beta \mathrm{CD}(\mathrm{T} 5-\mathrm{T} 3)$ \\
\hline T6: Soil with plantain + HA & 6.01 & 69.95 & 18.50 Humic acid (T6- T3) \\
\hline T7: Soil with plantain+ Tw 80 & 6.90 & 65.50 & 14.05 Tw 80 (T7- T3) \\
\hline 6 days & & & \\
\hline C:In autoclaved soil & 13.07 & 34.65 & 0.0 \\
\hline T1: In soil & 11.40 & 43.00 & 8.35 microorganisms $(\mathrm{T} 1-\mathrm{C})$ \\
\hline T2: Autoclaved soil with plantain & 8.29 & 58.55 & 23.90 Plant (T2-C) \\
\hline T3: Soil with plantain & 7.87 & 60.65 & 26.00 Combination (T3-C) \\
\hline T4: Soil with plantain+SiO2 & 3.47 & 82.65 & $22.00 \mathrm{SiO} 2(\mathrm{~T} 4-\mathrm{T} 3)$ \\
\hline T5: Soil with plantain + HPßCD & 4.20 & 79.00 & $18.35 \mathrm{HP} \beta \mathrm{CD}$ (T5- T3) \\
\hline T6: Soil with plantain+ HA & 3.90 & 80.50 & 19.85 Humic acid (T6- T3) \\
\hline T7: Soil with plantain+ Tw 80 & 4.70 & 76.50 & 15.85 Tw 80 (T7- T3) \\
\hline 8 days & & & \\
\hline C:In autoclaved soil & 11.50 & 42.50 & 0.0 \\
\hline T1: In soil & 9.05 & 54.75 & 12.25 microorganisms (T1-C) \\
\hline T2: Autoclaved soil with plantain & 6.00 & 70.00 & 27.50 Plant (T2-C) \\
\hline T3: Soil with plantain & 5.66 & 71.70 & 29.20 Combination (T3-C) \\
\hline T4: Soil with plantain+SiO2 & 1.50 & 92.50 & $20.80 \mathrm{SiO} 2(\mathrm{~T} 4-\mathrm{T} 3)$ \\
\hline T5: Soil with plantain + HPßCD & 1.72 & 91.40 & 19.70 HP $\beta C D(\mathrm{~T} 5-\mathrm{T} 3)$ \\
\hline T6: Soil with plantain + HA & 1.60 & 92.50 & 20.80 Humic acid (T6- T3) \\
\hline T7: Soil with plantain+ Tw 80 & 2.30 & 88.50 & 16.80 Tw $80($ T7 $-\mathrm{T} 3)$ \\
\hline
\end{tabular}


The potential of $P$. major for phytoremediation of pymetrozine in a the solution amended with $\mathrm{SiO}_{2}\left(\mathrm{~T}_{4}\right)$ was greater than those amended by other solubility enhancing agents, as measured by the removal of pymetrozine from contaminated soil at all experimental periods (Table 2). The percentage removal of pymetrozine through 4 days was $\sim 73.50 \%$ in $\mathrm{T}_{4}$. In addition to, the removal percentages of pymetrozine in $\mathrm{T}_{6}, \mathrm{~T}_{5}$, and $\mathrm{T}_{7}$ were $69.95 \%, 67.75 \%$, and $65.50 \%$. The contribution of $\mathrm{T}_{4}$ to the release of pymetrozine from soil was $22.05 \%$ while the contributions of $\mathrm{T}_{6}, \mathrm{~T}_{5}$, and $\mathrm{T}_{7}$ were $18.50 \%, 16.30 \%$, and $14.05 \%$ (Table 2). Results in Table 2 indicat that, the maximum contribution of $\mathrm{T}_{1}, \mathrm{~T}_{2}, \mathrm{~T}_{3}, \mathrm{~T}_{5}$, $\mathrm{T}_{6}$, and, $\mathrm{T}_{7}(12.25 \%, 27.50 \%, 29.20 \%, 19.70 \%$, $20.80 \%$, and $16.80 \%$ ) to the release of pymetrozine from soil during 8 days, while, $\mathrm{T}_{4}$ during 4 days cleared (22.05\%) (Table 2).

The above results showed that, most of the pymetrozine disappearance in $\mathrm{T}_{2}-\mathrm{T}_{8}$, may be attributed to bioavailability of pymetrozine by enhancing agents. Romeh (2015b) found that the phytoremediation potential of $P$. major plus liquid silicon dioxide, $\mathrm{SiO}_{2}$ was more potent than other solubility enhancing agents in removing cyanophos from the contaminated soil, improving removal percentage to $74.05 \%$ from $45.90 \%$ in soil with P. major only.

\section{Improvement the Phytoremediation of Soil Contaminated with Pymetrozine Using Soluble-Enhancing Agents}

Pymetrozine amounts $(\mathrm{mg} / \mathrm{kg})$ in the roots and leaves of $P$. major are shown in Table 3. Pymetrozine accumulated in the roots of $P$. major to reach the maximum levels after 4 days $(53.41 \mathrm{mg} / \mathrm{kg})$. Afterwards, the concentration decreased gradually throughout the test (Table $3)$. In the leaves, pymetrozine translocated into the $P$. major leaves and reached the maximum after 4 days of exposure $(58.08 \mathrm{mg} / \mathrm{kg})$, then decreased until the end of testing. In autoclaved soil with $P$. major, pymetrozine accumulated in the roots of $P$. major to reach the maximum level after 4 days $(52.67 \mathrm{mg} / \mathrm{kg})$. Afterwards, concentration decreased gradually throughout the test (Table 3). Pymetrozine translocated into the leaves of $P$. major and reached the maximum through 4 days of exposure $(57.72$ $\mathrm{mg} / \mathrm{kg}$ ) then declined until the end of testing. Liquid silicon dioxide $\left(\mathrm{SiO}_{2}\right)$ produced a synergistic effect on pymetrozine uptake and translocation. The phytoremediation potential of $P$. major plus $\mathrm{SiO}_{2}$ was greater than that of other solubility-enhancing agents with respect to the removal of pymetrozine from contaminated soil within 1-12 days exposure (Table 3). Amending the soil with $P$. major containing $\mathrm{SiO}_{2}$ resulted in a decrease in pymetrozine, half-life $\mathrm{T}_{1 / 2} ; \mathrm{k}_{\mathrm{r}}$, disappearance rate constant; AUCs, areas under the curve represent compound concentration during the period of study in the soil, and increased pymetrozine concentrations in plant leaves and roots (Table 3); it was detected in roots after one day then increased gradually and reached the maximum after 4 days $(91.25$ $\mathrm{mg} / \mathrm{kg}$ ) then decreased to the end of experiment. The pymetrozine concentration in P. major roots amended with $\mathrm{SiO}_{2}$ increased by about $170.84 \%$ compared to those treated with pymetrozine in $P$. major roots alone through 4 days. The pymetrozine concentrations in $P$. major roots amended with $\mathrm{SiO}_{2}, \mathrm{HA}, \mathrm{HP} \beta \mathrm{CD}$ and Tween 80 achieved $91.25 \mathrm{mg} / \mathrm{kg}, 87.50 \mathrm{mg} / \mathrm{kg}, 86.12$ $\mathrm{mg} / \mathrm{kg}$, and $58.04 \mathrm{mg} / \mathrm{kg}$ within 4 days, respectively. Pymetrozine concentrations in $P$. major roots alone reached $53.41 \mathrm{mg} / \mathrm{kg}$ (Fig. 2). Combination of $P$. major with enhancing agents for the purpose of pymetrozine phytoremediation in roots and leaves followed the order: $\mathrm{SiO}_{2}>\mathrm{HA}>\mathrm{HP} \beta \mathrm{CD}>$ Tween. $\mathrm{SiO}_{2}$ addition caused increased pymetrozine translocation to leaves by about $322.83 \%$ compared with $P$. major leaves alone through 4 days. The concentrations of pymetrozine in $P$. major enhanced with $\mathrm{SiO}_{2}$, $\mathrm{HA}, \mathrm{HP} \beta \mathrm{CD}$ and Tween 80 reached $187.50 \mathrm{mg} / \mathrm{kg}, 176.87 \mathrm{mg} / \mathrm{kg}$, $105.12 \mathrm{mg} / \mathrm{kg}$, and $94.25 \mathrm{mg} / \mathrm{kg}$ through 4 days, respectively. Pymetrozine concentrations in $P$. major leaves alone reached $58.08 \mathrm{mg} / \mathrm{kg}$.

The total pymetrozine accumulation in entire plant amended with $\mathrm{SiO}_{2}, \mathrm{HA}, \mathrm{HP} \beta \mathrm{CD}$ and Tween 80 arrived $278.75 \mathrm{mg} / \mathrm{kg}, 264.37 \mathrm{mg} / \mathrm{kg}$, $191.24 \mathrm{mg} / \mathrm{kg}$, and $152.29 \mathrm{mg} / \mathrm{kg}$ during 4 days compared with $111.49 \mathrm{mg} / \mathrm{kg}$ in $P$. major alone. Soil containing $P$. major and amended with $\mathrm{SiO}_{2}$ caused a decrease in pymetrozine in soil and increases in plant leaves and roots, which is explained by the silicic acid $\mathrm{Si}(\mathrm{OH})_{4}$ that enhance availability of compound from the soil to the roots and leaves of plant (Ma and Yamaji, 
Table 3. Efficiency of solubility-enhancing agents in phytoremediation of pymetrozine contaminated soil

\begin{tabular}{|c|c|c|c|c|c|c|c|c|c|}
\hline \multirow[t]{2}{*}{ Treatment } & \multicolumn{9}{|c|}{ Days after application } \\
\hline & 1 & 2 & 4 & 6 & 8 & $\overline{12}$ & $\begin{array}{c}\mathbf{t}_{1 / 2} \\
(\text { days })\end{array}$ & $\begin{array}{c}K_{\mathrm{r}} \\
\text { (days) }\end{array}$ & $\begin{array}{c}\mathrm{AUC}_{\mathrm{s}} \mathbf{m g} / \mathrm{kg} \\
\text { (days) }\end{array}$ \\
\hline $\begin{array}{l}\mathrm{In} \mathrm{soil} \\
\mathrm{mg} / \mathrm{kg}\end{array}$ & 17.50 & 15.30 & 13.52 & 11.40 & 9.05 & 7.62 & 8.58 & 0.08 & 142.19 \\
\hline Loss (\%) & 12.50 & 23.50 & 32.40 & 43.00 & 54.75 & 61.90 & & & \\
\hline $\begin{array}{l}\text { In soil with } P . \text { major } \\
\mathrm{mg} / \mathrm{kg}\end{array}$ & 14.00 & 11.52 & 9.71 & 7.87 & 5.66 & 3.35 & 565 & 0.12 & 97.45 \\
\hline Loss (\%) & 30.00 & 42.40 & 51.45 & 60.65 & 71.70 & 83.25 & & & \\
\hline $\begin{array}{l}\text { In } P \text {. major roots } \\
\mathrm{mg} / \mathrm{kg}\end{array}$ & 38.74 & 45.56 & 53.41 & 42.91 & 37.69 & 22.58 & & & \\
\hline $\mathrm{mg} / \mathrm{kg}$ & 13.58 & 44.95 & 58.08 & 37.72 & 28.13 & 16.06 & & & \\
\hline $\begin{array}{l}\text { Total uptake } \\
\text { In soil with } P \text {. major + HPßCD }\end{array}$ & 52.32 & 90.51 & 111.49 & 80.63 & 65.82 & 38.64 & & & \\
\hline $\begin{array}{l}\mathrm{mg} / \mathrm{kg} \\
\mathrm{Loss}(\%)\end{array}$ & $\begin{array}{l}11.20 \\
44.00\end{array}$ & $\begin{array}{c}8.24 \\
58.80\end{array}$ & $\begin{array}{c}6.45 \\
67.75\end{array}$ & $\begin{array}{c}4.20 \\
7900\end{array}$ & $\begin{array}{c}1.72 \\
9140\end{array}$ & $\begin{array}{c}0.16 \\
9920\end{array}$ & 3.10 & 0.22 & 57.84 \\
\hline In $P$. major roots & & & & & & & & & \\
\hline $\begin{array}{l}\mathrm{mg} / \mathrm{kg} \\
\text { In } P \text {. major leaves }\end{array}$ & 56.22 & 72.63 & 86.12 & 70.19 & 60.05 & 35.09 & & & \\
\hline $\mathrm{mg} / \mathrm{kg}$ & 43.15 & 80.12 & 105.12 & 65.43 & 47.66 & 26.85 & & & \\
\hline $\begin{array}{l}\text { Total uptake } \\
\text { In soil with } P \text { maigr }+ \text { Tween } 80\end{array}$ & 99.37 & 152.75 & 191.24 & 135.62 & 107.71 & 61.94 & & & \\
\hline $\begin{array}{l}\text { In soil with } P . \text { major + Tween } 80 \\
\mathrm{mg} / \mathrm{kg} \\
\text { Loss }(\%)\end{array}$ & $\begin{array}{l}11.60 \\
42.00\end{array}$ & $\begin{array}{c}8.80 \\
56.00\end{array}$ & $\begin{array}{c}6.90 \\
65.50\end{array}$ & $\begin{array}{c}4.70 \\
76.50\end{array}$ & $\begin{array}{c}2.30 \\
88.50\end{array}$ & $\begin{array}{c}0.60 \\
97.00\end{array}$ & 3.41 & 0.20 & 63.28 \\
\hline $\begin{array}{l}\text { In } P \text {. major roots } \\
\mathrm{mg} / \mathbf{k g}\end{array}$ & & 5380 & 5804 & 1761 & 4047 & 3007 & & & \\
\hline In $P$. major leaves & 46.26 & 53.80 & 50.04 & 47.01 & 40.42 & 30.92 & & & \\
\hline $\mathrm{mg} / \mathrm{kg}$ & 37.09 & 64.74 & 94.25 & 57.62 & 36.82 & 20.13 & & & \\
\hline Total uptake & 83.35 & 118.54 & 152.29 & 105.23 & 77.24 & 51.05 & & & \\
\hline $\begin{array}{l}\text { In soil with p. major }+\mathrm{SiO}_{2} \\
\mathrm{mg} / \mathrm{kg} \\
\mathrm{Loss}(\%)\end{array}$ & $\begin{array}{l}11.10 \\
44.50\end{array}$ & $\begin{array}{c}7.42 \\
62.90\end{array}$ & $\begin{array}{c}5.30 \\
73.50\end{array}$ & $\begin{array}{c}3.47 \\
82.65\end{array}$ & $\begin{array}{c}1.50 \\
92.50\end{array}$ & $\begin{array}{c}0.01 \\
99.95\end{array}$ & 2.66 & 0.26 & 51.05 \\
\hline $\begin{array}{l}\text { In } P \text {. major roots } \\
\mathrm{mg} / \mathbf{k g} \\
\text { In } \boldsymbol{P} \text {. major leaves }\end{array}$ & 45.41 & 65.62 & 91.25 & 56.25 & 35.00 & 0.00 & & & \\
\hline $\mathrm{mg} / \mathrm{kg}$ & 125.25 & 156.21 & 187.50 & 133.75 & 90.37 & 6.25 & & & \\
\hline $\begin{array}{l}\text { Total uptake } \\
\text { In soil with } P \text {. major }+ \text { HA }\end{array}$ & 170.66 & 221.83 & 278.75 & 190.00 & 125.37 & 6.25 & & & \\
\hline $\begin{array}{l}\mathrm{mg} / \mathrm{kg} \\
\mathrm{Loss}(\%)\end{array}$ & $\begin{array}{l}11.16 \\
44.20\end{array}$ & $\begin{array}{c}7.71 \\
61.45\end{array}$ & $\begin{array}{c}6.01 \\
69.95\end{array}$ & $\begin{array}{c}3.90 \\
80.50\end{array}$ & $\begin{array}{c}1.60 \\
92.00\end{array}$ & $\begin{array}{c}0.05 \\
99.75\end{array}$ & 2.92 & 0.23 & 54.65 \\
\hline $\begin{array}{l}\text { In } P \text {. major roots } \\
\mathbf{m g} / \mathbf{k g}\end{array}$ & & & & & & & & & \\
\hline $\begin{array}{l}\mathrm{mg} / \mathrm{kg} \\
\text { In } P \text {. major leaves }\end{array}$ & 55.61 & 68.75 & 87.50 & 22.50 & 15.00 & 0.00 & & & \\
\hline $\mathrm{mg} / \mathrm{kg}$ & 36.25 & 126.25 & 176.87 & 131.25 & 56.25 & 12.50 & & & \\
\hline $\begin{array}{l}\text { Total uptake } \\
\text { In autoclaved }\end{array}$ & 91.86 & 195.00 & 264.37 & 153.75 & 71.25 & 12.50 & & & \\
\hline $\begin{array}{l}\text { In autoclaved } \\
\mathrm{mg} / \mathrm{kg} \\
\operatorname{Loss}(\%)\end{array}$ & $\begin{array}{l}14.30 \\
28.50\end{array}$ & $\begin{array}{l}12.00 \\
40.00\end{array}$ & $\begin{array}{l}10.10 \\
49.50\end{array}$ & $\begin{array}{c}8.29 \\
58.55\end{array}$ & $\begin{array}{c}6.00 \\
70.00\end{array}$ & $\begin{array}{c}3.90 \\
80.50\end{array}$ & 6.01 & 0.11 & 102.44 \\
\hline $\begin{array}{l}\text { In } P \text {. major roots } \\
\mathrm{mg} / \mathrm{kg} \\
\text { In } P \text {. major leaves }\end{array}$ & 37.31 & 44.86 & 52.67 & 41.70 & 36.46 & 21.99 & & & \\
\hline $\mathrm{mg} / \mathrm{kg}$ & 17.34 & 43.46 & 57.72 & 36.88 & 27.26 & 15.68 & & & \\
\hline $\begin{array}{l}\text { Total uptake } \\
\text { In autoclaved soil }\end{array}$ & 54.65 & 88.32 & 110.39 & 78.58 & 63.72 & 37.67 & & & \\
\hline $\mathrm{mg} / \mathrm{kg}$ & 18.55 & 17.39 & 15.06 & 13.07 & 11.50 & 9.20 & 10.48 & 0.06 & 163.52 \\
\hline Loss $(\%)$ & 7.25 & 13.05 & 24.70 & 34.65 & 42.50 & 54.00 & & & \\
\hline
\end{tabular}


Zagazig J. Agric. Res., Vol. 44 No. (2) 2017

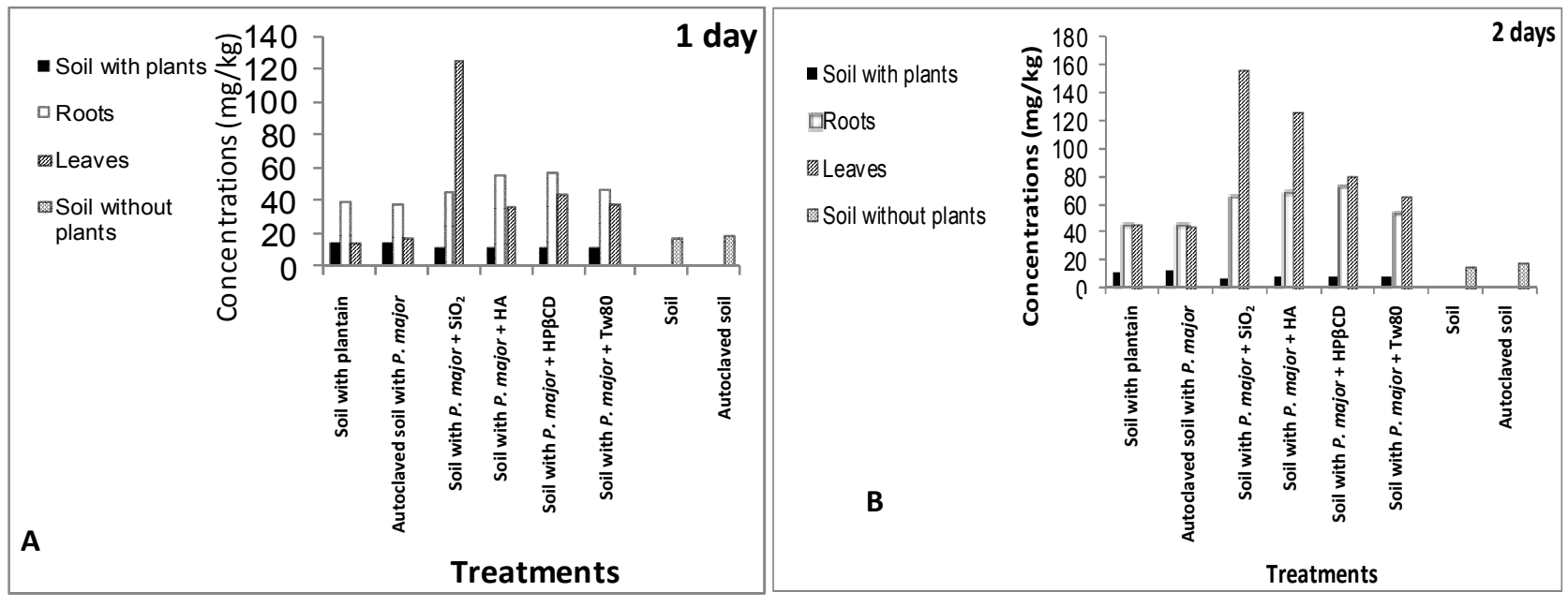

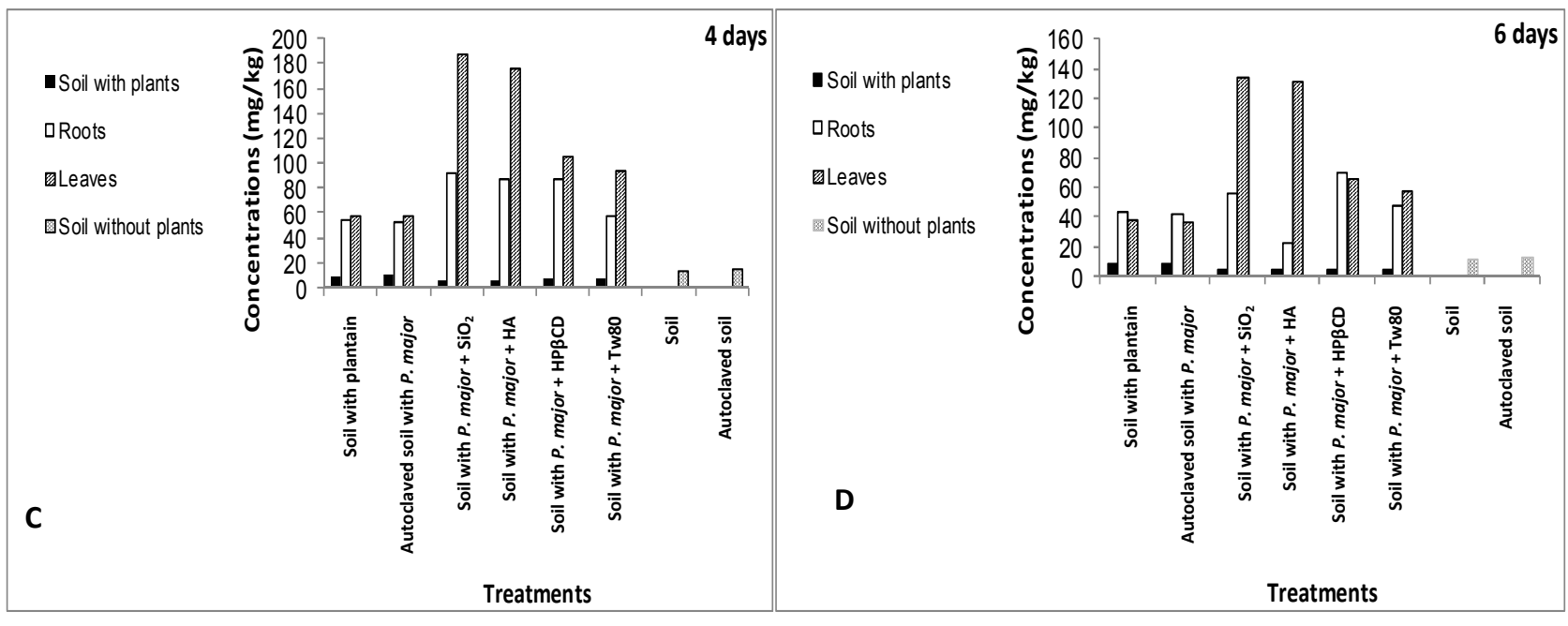

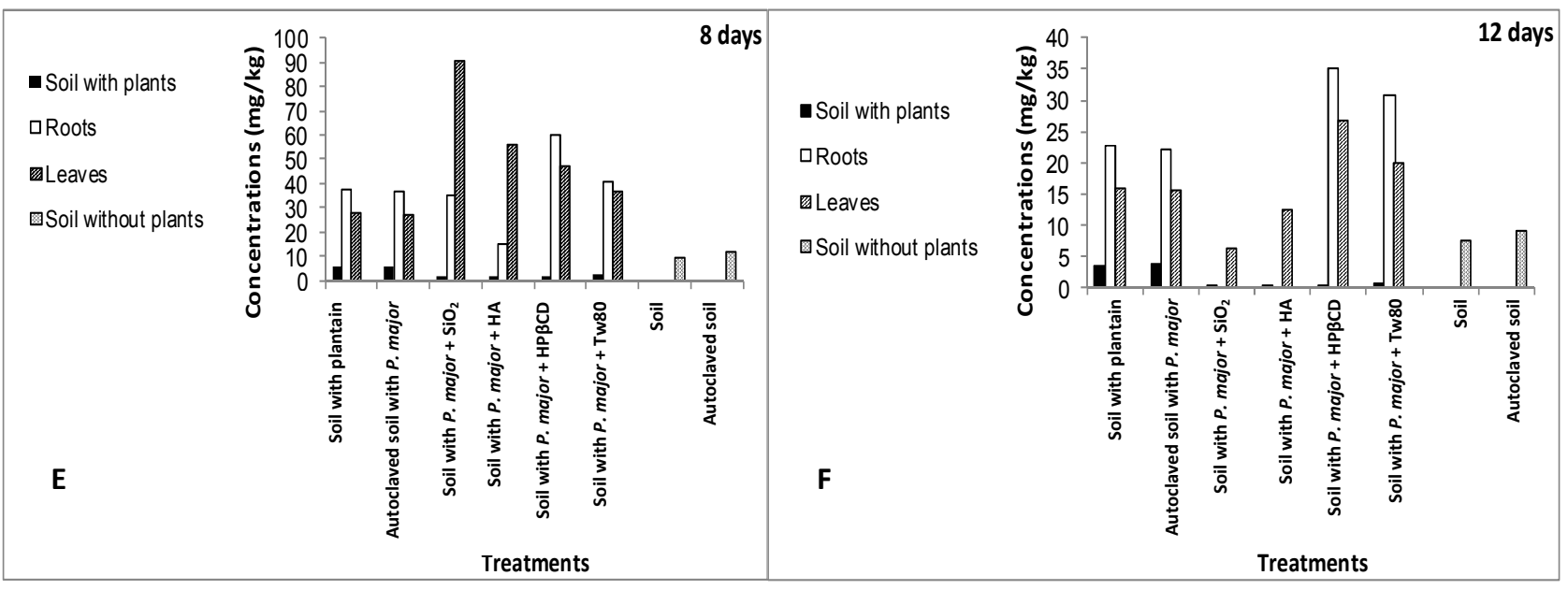

Fig. 2. Efficiency of solubility enhancing agents in phytoremediation of pymetrozine contaminated soil through 1-12 days of exposure; HPßCD: 3- hydroxyl, B-cyclodextrin, Tw 80: tween 80, $\mathrm{SiO}_{2}$ : silicon dioxide, HA: humic acid; (A): 1 day, (B): 2 days, (C): 4 days, (D): 6 days, (E): 8 days, (F): 12 days 
2006). In addition to, humic acid (HA) caused a synergistic effect on pymetrozine uptake and translocation. Humic acid (HA) could act as a natural surfactant for enhancing the bioavailability of pymetrozine -contaminated soil. The combined effects of plants plus HA resulted in increasing the removal amount of pymetrozine from the soil, enhancing percentage degradation of $69.95 \%$ from $51.45 \%$ in soil with $P$. major only through 4 days of treatment (Table 3). The enhanced degradation performance for pymetrozine observed might be due to an increase in microbial activities and bioavailable in soils caused by the combined effects of plants and HA. Also, results in Table 3 show that HA was a little bit better than Tween 80 in decreasing pymetrozine - polluted soil. The surfactant activity of HA was found to increase solubility of organic contaminants on soils, hence enabling desorption-remediation of polycyclic aromatic hydrocarbon (PAH) (Holman et al., 2002), In addition to, the fraction of humic substances remaining in the soil cause a favorable role in the growth of plant and microbes and thus useful in the full recuperation of treated soils (Nardi et al., 2002). Several reports discussed the use of surfactantenhanced phytoremediation (Mitton et al., 2012). This work also showed that enhancing agents such as the surfactants, $\mathrm{HP} \beta \mathrm{CD}$, natural $\mathrm{HA}$ and Tween 80 removes amounts convergent of pymetrozine from a contaminated soil (Fig. 2). $\mathrm{HP} \beta C D$ helped in recovering $86.12 \mathrm{mg} / \mathrm{kg}$ and $105.12 \mathrm{mg} / \mathrm{kg}$ pymetrozine from contaminated soil by $P$. major roots and leaves within 4 days of treatment (Fig. 2). This increase in the removal of pymetrozine in soils amended with HP $\beta C D$ may be due to the formation of an inclusion complex with pymetrozine (Villaverde et al., 2006). The use of plants plus surfactants has been proposed for improving phytoremediation strategies. These methods are based on the ability of agents to enhance the water solubility of hydrophobic organic compounds (HOCs) and to promote desorption, bio-degradation and phytoremediation processes (Wang and Keller, 2009).

\section{Conclusion}

The results showed that $P$. major removes efficiently of pymetrozine residues in soil and has a potential activity for pesticides phytoremediation. Also, this study indicates that $\mathrm{SiO}_{2}$ can enhance the phytoremediation effectiveness for pymetrozine.

\section{REFERENCES}

Anastassiades, M., S.J. Lehotay, D. Stajnbaher and F. Schenck (2003). Fast and easy multiresidue method employing acetonitrile extraction/partitioning and "dispersive solidphase extraction" for the determination of pesticide residues in produce. J. AOAC. Int., 86: 412-431.

Asensio-Ramos, M., J. Hernández-Borges, L.M. Ravelo-Pérez and M.A. Rodríguez-Delgado (2010). Evaluation of a modified QuEChERS method for the extraction of pesticides from agricultural, ornamental and forestal soils. Anal. Bioanal. Chem., 396 (6): 2307-2319.

Ashour, M.B.A. (1976). Residual effect of certain soil pesticides on some field crops. M.Sc. Thesis, Fac. Agric., Zagazig Univ., Egypt.

Chen, Y., X. Tang, S.A. Cheema, W. Liu and C. Shen (2010). Beta cyclodextrin enhanced phytoremediation of aged PCBscontaminated soil from waste recycling area. J. Environ. Monit., 12: 1482-1489.

Cheng, S., X. Jin, X. Huiping, Z. Liping and W. Zhenbin (2007). Technical note phytoremediation of triazophos by canna indica L. in a hydroponic system. Int. J. Phytoremediation, 9: 453-463.

Edwards, D.A., R.G. Luthy and Z. Liu (1991). Solubilization of polycyclicaromatic hydrocarbons in micellar nonionic surfactant solutions. Environ. Sci. Technol., 25: 127133.

EFSA (European Food Safety Authority) (2014). Conclusion on the peer review of the pesticide risk assessment of the active substance pymetrozine. EFSA J., 12 (9): 3817.

Escalante-Espinosa, E., M.E. GallegosMartinez, E. Favela-Torres and M. GutiérrezRojas (2005). Improvement of the hydrocarbon phytoremediation rate by 
Cyperus laxus Lam. inoculated with a microbial consortium in a model system, Chemosphere, 59: 405-413.

Fliickige, C.R., H. Kristinson, R. Senn, A. Rindlisbacher, H. Buholzer and G. Voss (1992). A novel agent to control aphids and whiteflies. Brighton Crop Protection Conf. Pests and Diseases, 1: 43-50.

Gomaa, E.A. and M.H. Belal (1975). Determination of dimethoate residues in some vegetables and cotton plant. Zagazig J. Agric. Res., 2: 215-221.

Guetzloff, T.F. and J.A. Rice (1994). Does humic acid form amicelle?. Sci. Total Environ., 152: 31-35.

Guoqing, S., H. Xuan and H. Yinan (2009). Kinetic study of the degradation of the insecticide pymetrozine in a vegetable-field ecosystem. J. Hazard Mater, 164: 497-501.

Holman, H., K. Nieman, D. Sorensen, C. Miller, M.C. Martin, T. Borch, W. McKinney and R. Sims (2002). Catalysis of PAH biodegradation by humic acid shown in synchroton infrared studies. Environ. Sci. Technol., 36: 1276-1280.

Lashkari, M.R., A. Sshragard and M. Ghadamyari (2007). Sublethal effects of imidacloprid and pymetrozine on population growth parameters of cabbage aphid, Brevicoryne brassicae on rapeseed, Brassica napus L. Insect Sci., 14: 207.

Lehotay, S.J., K. Mas`tovska'and S.J. Yun (2005). Evaluation of two fast and easy methods for pesticide residue analysis in fatty food matrixes. J. AOAC. Int., 88: 630638.

Ma, J.F. and N. Yamaji (2006). Silicon uptake and accumulation in higher plants. Trends Plant Sci., 11: 392-397.

Mitton, F.M., G. Mariana, P. Aranzazu and S. Karina (2012). Effects of amendments on soil availability and phytoremediation potential of aged p, p-DDT, p, p_-DDE and p, p-DDD residues by willow plants (Salix sp.). J. Hazard. Mater., 203-204: 62-68.

Nardi, S., E. Sessi, D. Pizzeghello, A. Sturaro, R. Rella and G. Pargoli (2002). Biological activity of soil organic matter mobilized by root exudates. Chemosphere, 46: 1075-1081.

Padilla-Sanchez, J.A., P. Plaza-Bolanos, R. Romero-Gonzalez, A. Garrido-Frenich and J.L.M. Vidal (2010). Application of a quick, easy, cheap, effective, rugged and safe-based method for the simultaneous extraction of chlorophenols, alkylphenols, nitrophenols and cresols in agricultural soils, analyzed by using gas chromatography-triple quadrupolemass spectrometry/mass spectrometry. J. Chromatography A. 1217 (36): 5724 - 5731.

Romeh, A.A. (2010). Phytoremediation of water and soil contaminated with imidacloprid pesticide by plantago major L. Int. J. Phytoremediation, 12: 188-199.

Romeh, A.A. (2013). Diethyl phthalate and dioctyl phthalate in Plantago major L. Afri. J. Agric. Res., 8: 4360-4364.

Romeh, A.A. (2014). Phytoremediation of cyanophos insecticide by Plantago major L. in water. J. Environ. Health Sci. and Eng., 12: 38 .

Romeh, A.A. (2015a). Evaluation of the phytoremediation potential of three plant species for azoxystrobin-contaminated soil. Int. J. Environ. Sci. Technol., 12 : 35093518 .

Romeh, A.A. (2015b). Enhancing agents for phytoremediation of soil contaminated by cyanophos. Ecotoxicol. and Environ. Safety 117: 124-131.

Romeh, A.A. and M.Y. Hendawi (2013). Chlorpyrifos insecticide uptake by plantain from polluted water and soil. Environ. Chem. Lett., 11:163-170.

Samuelsen, A.B. (2000). The traditional uses, chemical constituents and biological activities of Plantago major L.: a review. J Ethnopharmacol, 71: 1-21.

Sharifa, A.A., Y.L. Neoh, M.I. Iswadi, O. Khairul, M.M. Abdul Halim, A. Jamaludin Mohamed and H.L. Hing (2008). Effects of methanol, ethanol and aqueous extract of Plantago major on gram positive bacteria, gram negative bacteria and yeast. Ann. Microsc., 8: 42-44. 
Shen, G., X. Hu and Y. Hu (2009). Kinetic study of the degradation of the insecticide pymetrozine in a vegetable-field ecosystem. J. Hazard. Mater., 164 (2-3): 497-501.

Siciliano, S.D. and J.J. Germida (1998). Mechanisms of phytoremediation: biochemical and ecological interactions between plants and bacteria. Environ. Rev., 6 (1): 65-79.

Velasco-Lezama, R., R. Tapia-Aguilar, R. Román-Ramos, E. Vega-Avila and M.S. Perez-Gutierrez (2006). Effect of Plantago major on cell proliferation in vitro. J. Ethnopharmacol., 103 (1): 36-42.
Villaverde, J., C. Maqueda and E. Morillo (2006). Effect of the simultaneous addition of cyclodextrin and the herbicide norflurazon on its adsorption and movement on soils. J. Agric. and Food Chem., 54: 4766-4772.

Wang, P. and A.A. Keller (2009). Partitioning of hydrophobic pesticides within a soil-wateranionic surfactant system, Water Res., 43: $706-714$.

Wyss, P. and M. Bolsinger (1997). Translocation of pymetrozine in plants. Pestic. Sci., 50: 195-202.

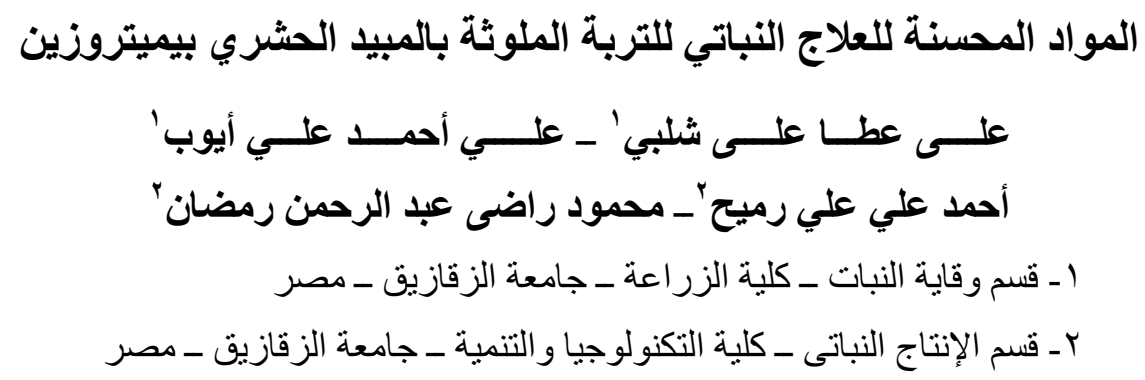

تم تصميم هذا البحث لدراسة أهمية استخدام نبات لسان الحمل (Plantago major L.) في المعالجة النباتية للتربة

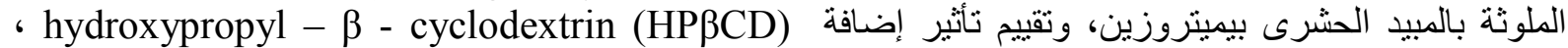
liquid humic acid (HA) Tween 80 ، silicon dioxide $\left(\mathrm{SiO}_{2}\right)$

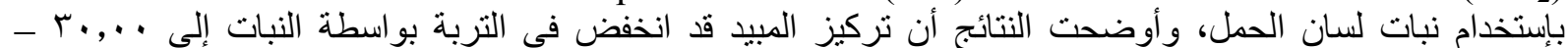

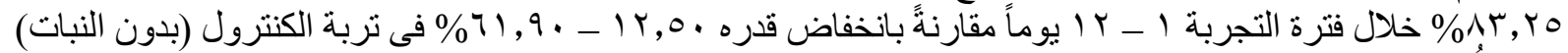

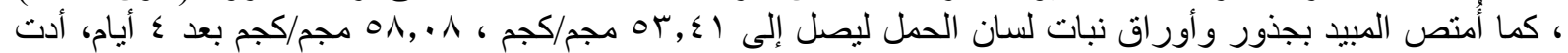

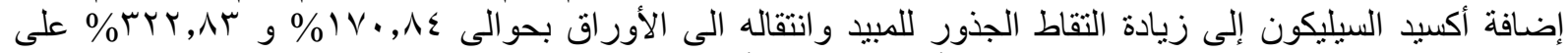

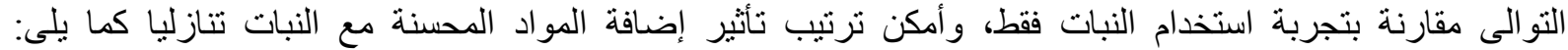
لإبه للتربة الملوثة بهذا المبيد. 